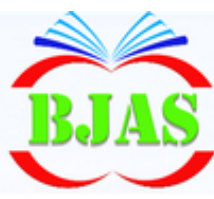

ISSN $1814-5868$
Available online at http://bjas.bajas.edu.iq

https://doi.org/10.37077/25200860.2020.33.2.15

College of Agriculture, University of Basrah

Basrah J. Agric. Sci., 33(2): 172-181, 2020

\section{Basrah Journal of Agricultural Sciences}

E-ISSN: 2520-0860

\title{
Trophic levels of Tidal and Non-Tidal Marshes of Southern Mesopotamia
}

\author{
Najah A. Hussain ${ }^{1} \&$ Amal A. Sabbar ${ }^{2 *}$ \\ ${ }^{1}$ Department of Ecology, College of Science, University of Basrah, Iraq. \\ ${ }^{2}$ Department of Protection and Improvement the Environment in the Southern Region, \\ Basrah, Iraq \\ *Corresponding author e-mail: amalalisabbar@yahoo.com \\ Received 22 July 2020; Accepted 15 October 2020; Available online 23 October2020
}

\begin{abstract}
Carlson's Trophic State Index (CTSI) was applied to assess the trophic status of two kind of southern Mesopotima marshes. Six stations were selected, three in non-tidal Chebiyesh marshes and other three in tidal East Hammer marsh. The results indicated that the values of CTSI of the six stations fluctuated between 47.59 - 61.96 ranged from mesotrophic to Eutrophic. The increase of salinity during 2018 drastically affect CTSI values in East Hammer marsh. In general, both tidal and non-tidal marshes were eutrophic mainly due to direct release of untreated domestic swage and agricultural drainage waters. Trophic status of southern Iraqi marshes potentially impacted by transparency of the marsh, chlorophyll a and phospharus concentrations.

Keywords: Carlson's Trophic State Index, Trophic level Iraqi marshes, Mesopotamia marshes trophic index.
\end{abstract}

\section{Introduction}

The southern Iraqi marshes occupy the south and south eastern parts of the Mesopotamian valley. The climate of the area experience prolonged very hot summer and rather short cold winters. North-westerly winds were the most dominant ones with a pronounced influence on the area (Yuaqub \& Salman 1992).

Tigris and Euphrates and Shatt Al-Arab rivers are the main sources freshwater to southern marshes. The water of the middle marshes is resultant of the mixing of Tigris; Euphrates rivers, while the western marshes derived its waters from Euphrates. Qurna and Huwayzah marshes take its water from Tigris. West Hammar marsh received its water from Euphrates and the eastern part from Shatt AlArab river (Taher et al., 2008).
The southern marshes are a unique ecosystem surrounded by vast arid middle east zone. It contains several biotopes and rich biodiversity. its play as refuge for millions of migrating birds from western Asia and northern Europe beside consider as spawning and feeding grounds for several marine fishes and shrimp migrating from the Arabian Gulf. (Richardson \& Hussain, 2006; Hussain, 2014).

The southern marshes were subjected to planed dissection led to disappear of $85 \%$ of its environment, after 2003 it was inundated again and the marshes started to be recovered and restored. The southern marshes as one of the few populated wetlands in world, consequently exposed to direct discharge of untreated domestic and agricultural wastewater loaded by nutrients and heavy 
metals (Hussain et al., 2009; Al-Asadi \& AlHejuje, 2019).

The water quality index (WQI) of the southern marshes was ranged from low to moderate as affected by temporal and spatial variations (Hussain \& Taher, 2007).

Hussain \& Grabe (2009) postulated that salinity values of southern marshes increased over time due to decrease in freshwater inflow from Tigris and Euphrates, adversely altering marsh environment to be mesosaline in several localities. Dissolved oxygen levels were in sufficient concentrations for existence of huge aquatic biota. Marsh waters were slightly alkaline. Extensive submerged aquatic vegetation facilitates the settling of suspended solids. Nitrates are the predominant form of inorganic nitrogen and are the limiting factor for the algal primary production while phosphorus and silicate found to be in sufficient concentration, where the later of enough level to facilitate phytoplankton growth.

Trophic state is defined as the total weight of the biomass in a water body at a specific location and time. Trophic state is the biological response for nutrient additions to the water bodies. Carlson's trophic state index mainly uses to calculate trophic index with the help of three variables namely Chlorophyll-a (Chl-a), Transparency and Total phosphate (TP). (Devi Prasad \& Siddaraju, 2012). The purpose of the present study is to quantify the trophic levels of Iraqi southern marshes by using the trophic State Index (TSI) to quantify the difference between tidal and the non-tidal marshes of southern Iraq.

\section{Materials \& Methods}

East Hammer marsh:

East Hammer marsh represent the south eastern part of the vast Iraqi southern marshes. Its length exceeds $33 \mathrm{~km}$ with Maximum water depth ranges from 1.2 -3.0 $\mathrm{m}$. depend on the status of the tide. It is a semi diurnal tidal marsh affect by tide from the Arabian Gulf via Shatt Al Arab river. The marsh was subjected to deliberate desiccation by Saddam regime during the nineties of last century .After inundation in 2003, the marsh exhibited the return of its flora and fauna with different percentage (Richardson \& Hussain, 2006). Due to the constriction of several irrigation dams on Tigris and Euphrates rivers in Turkey, Syria, Iran and Iraq, led to the reduce of freshwater flow qualitatively and quantitatively reached the southern marshes. The reduction in freshwater discharge to East Hammer marsh change the nature of marsh to be mesosaline (Hussain \& Taher, 2007) consequently altering its environment to be more favourable to marine/estuarine organisms. East Hammer marsh gets a considerable amount of water from Shatt Al-Arab river and groundwater recharge is another source of replenishment (Mohamed \& Hussain, 2012). with well oxygenated, grey mud-silt sediments with low total organic carbon (TOC), and an alkaline pH (Hussain \& Taher, 2007; Taher et al., 2008).

\section{Chebiyesh Marshes}

Chebiyesh marshes located in middle of the Central Marshes (Fig. 1) and major part of the biggest non-tidal southern marshes. The Tigris bound the central marshes from the east and the Euphrates from the west and south. The area is roughly delimited by between Nasiriyah, and Qurna cities. They area of the marsh varied seasonally depend on the water inflow from Euphrates river. The marsh faced 
a complete desiccation by Saddam regime by diverting the water inflow from Tigris river marshes. As a consequence, the unique aquatic habitats were vanished (Richardson \& Hussain, 2006). After inundation in 2003, the marshes were partially restored. Maximum water depth of Chybayish marshes ranges from 1.0-2.5 m. In 2006-2007. 27 species of and construction of the Al Ezz River in 1993. Lead to a complete dryness of the Chebiyesh hydrophytes were registered which gave a restoration percentage of aquatic macrophyte species at the level of $61.36 \%$. Almost the entire marsh was covered by reed canopy's of Phragmites australis and Typha domingensis, (Al-Abbawy \& Al-Mayah, 2010).

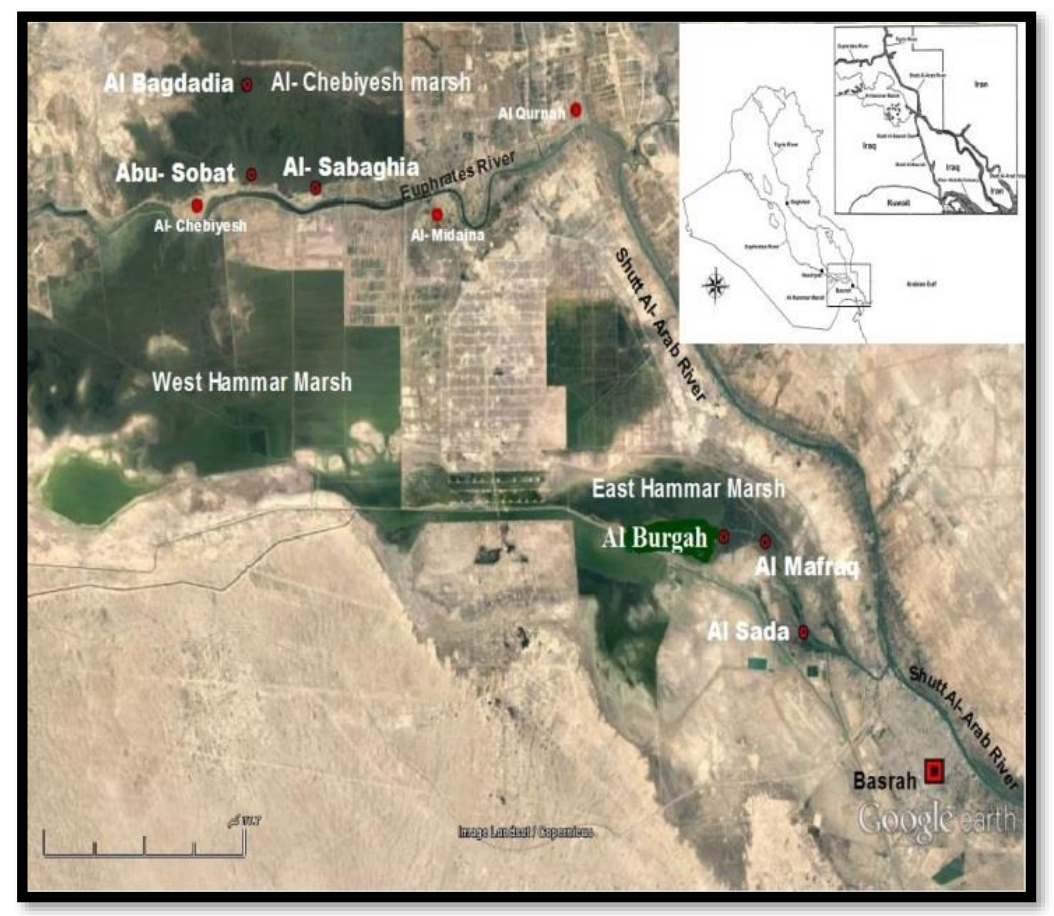

Fig. (1): Map showing southern marshes with designated six stations at tidal East Hammer marsh and non-tidal Chebiyesh marshes.

\section{Sampling stations}

Six stations were chosen to cover the southern mesopotamian marshes, three of them located at East Hammer marsh (semidiurnal tidal marsh) and the other three were in Chebiyesh marshes (non-tidal marsh), GPS coordinates of the stations are given in table (1).

\section{Water sampling and Analysis}

Duplicate seasonal water samples were collected from the designated six stations in both marshes during the period from Spring 2018 to Winter 2019. Water quality measurements include salinity, transparency, phosphorus, and Chlorophyll. The data of the last three are the input to find out the Carlson Trophic State Index (CTSI). Surface water samples were collected by using water sampler. In East Hammer marsh samples were collected during ebb tide to represent the actual marsh water depth. Salinity were measured by using salinity meter (WTW Multi meter i350).

Water transparency was measured by Secchi's disc of $30 \mathrm{~cm}$ in diameter and the values are expressed in $\mathrm{cm}$. The maximum depth at which the disc can be seen when 
Hussain\& Sabbar/ Basrah J. Agric. Sci., 33(2): 172-181, 2020

Table (1): Location of sampling stations in both East Hammer marsh (tidal) and Chebiyesh marshes (non- tidal) with their GPS readings and type environment of the marshes.

\begin{tabular}{|c|c|c|c|}
\hline Marsh & Station & Marsh Type & GPS \\
\hline \multirow{3}{*}{ East Hammar } & Al-Sada (ST1) & Inlet marsh & $\mathrm{N}: 30^{\circ} 36.556^{\prime}$ and $\mathrm{E}: 047^{\circ} 40.276^{\prime}$ \\
\hline & Al-Mafraq (ST2) & Channel marsh & $\mathrm{N}: 30^{\circ} 40.736^{\prime}$ and $\mathrm{E}: 47^{\circ} 37.847^{\prime}$ \\
\hline & Al-Burgah (ST3) & Openness marsh & $\mathrm{N}: 30^{\circ} 41.067^{\prime}$ and $\mathrm{E}: 047^{\circ} 34.955^{\prime}$ \\
\hline \multirow[t]{3}{*}{ Chebiyesh } & Al-Sabaghia (ST4) & Inlet marsh & $\mathrm{N}: 30^{\circ} 57.934^{\prime}$ and $\mathrm{E}: 047^{\circ} 06.956^{\prime}$ \\
\hline & Abu-Sobat (ST5) & Channel mrarsh & $\mathrm{N}: 30^{\circ} 58.694^{\prime}$ andE: $047^{\circ} 02.436^{\prime}$ \\
\hline & Al Baghdadia ST6) & Openness marsh & $\mathrm{N}: 31^{\circ} 02.931^{\prime}$ and $\mathrm{E}: 047^{\circ} 02.198^{\prime}$ \\
\hline
\end{tabular}

lowered in to the water is marked and measured. Total phosphorus was determined by the method described in APHA (2005). Chlorophyll a was estimated according to Lind (1979)

Trophic state index was calculated according to Carlson (1977) by applying the flowing formula - :

TSI $(\mathrm{SD})=60-14.41 \mathrm{Ln}($ Secchi disc depth (m. $(($

TSI $(\mathrm{Chl})=9.81 \mathrm{Ln}\left(\right.$ chlorophyll a $\left.\left(\mu \mathrm{g} . \mathrm{l}^{-1}\right)\right)$ $+30.6$

TSI $(\mathrm{TP})=14.42 \mathrm{Ln}\left(\right.$ total $\left.\operatorname{phosphorus}\left(\mu \mathrm{g} . \mathrm{l}^{-1}\right)\right)$ $+4.15$

Average $\mathrm{TSI}=[\mathrm{TSI}(\mathrm{TP})+\mathrm{TSI} \quad(\mathrm{Chl})+$ $\mathrm{TSI}(\mathrm{SD})] / 3$.
Based on the values of CTSI the marshes are classified as oligotrophic (low productive), mesotrophic (moderately productive), eutrophic (highly productive) and hypertrophic (very high productive). The scope of the Carlson's trophic state index values and classification of marshes are presented in table (2).

\section{Statistical Analysis}

ANOVA test (one-way) was applied using the application of the statistical analysis program spss version (23) to analyse the seasonal and spatial variations, the basic technique principal component analysis using PAST program was adopted to determine the most influential water quality variables determine the CTSI.

Table (2): TSI grade and their ecological attributes.

\begin{tabular}{ccc}
\hline Class & TSI & Ecological attributes \\
\hline $\mathbf{1}$ & $<30$ & Oligotrophic \\
\hline $\mathbf{2}$ & $40-50$ & Mesotrophic \\
\hline $\mathbf{3}$ & $50-70$ & Eutrophic \\
\hline $\mathbf{4}$ & $70-100$ & Hypertrophic \\
\hline
\end{tabular}




\section{Results \& Discussion}

The seasonal salinity gradients were higher in East Hammer marsh stations than that of Chebiyesh marshes particularly during summer and autumn (Table 3). The highest salinity values were recorded at Al-Burgah station 14.35 psu during summer 2018. East Hammer marsh experience mount increased in salinity during 2018, due to decrease in freshwater discharge from its tributaries and continuous intrusion of salt wedge from the Arabian Gulf (Al-Nagar et al.,2020).

The Carlson's trophic state index (CTSI) of the two marshes were showed in tables (4) and (5). The average values of the index during the study period were categorized as eutrophic in both marshes. The statistical analysis found significant differences between seasons, while they were insignificant differences between study station's in both marshes.

CTSI of East Hammar marsh fluctuated between 50.54 to 56.09 , the lower value recorded in Al-Sada station during summer (Table 4), due to strong tidal currents since it described as inlet marsh station. The increase of salinity in East Hammer marsh in 2018 led to the fluctuation of CTSI values. 2018 was an exceptional year experienced mount increase in salinity resulting in mass death of aquatic plants canopy and phytoplankton. (AlNagar et al., 2020), consequently affected largely the growth of aquatic plants in the marsh. Decrease in chlorophyll a concentration is one of the major factors inversely affected CTSI values. Hosmani (2010) pointed out that measurement of chlorophyll a can be used as a primary index for trophic state classification of water bodies, the highest values of CTSI was recorded at Al-Mafraq station during Autumn due to effluent of untreated domestic sewage from nearby Arab marsh settlements have large herds of water buffalo of the variations of CTSI in the Chebiyesh marshes displayed seasonal fluctuations especially at the AlBaghdadia station, which could be attributed to heavy rain deposition contributed in phosphate release from sediments as a result of increased mixing processes. Moreover, deposition from the air by rain and also the release of domestic sewage loaded with phosphate- compounds such domestic detergents and agricultural fertilizers and other wastewater (Al-Asadi \& Al-Hejuje, 2019).

Lowest value of CTSI recorded during spring season in Al-Sabaghia station (Table 5), may highly related to strong current from Euphrates river, as well as the low phosphorus value as a result of low agricultural activity in this station compared to other study stations. Carlson (1980) stated that total phosphorus is one of the main variables controlled the trophic index and directly correlated with its values. It is well known that tidal marshes are highly productive (Mitsch \& Gosselink, 2000). AlHilli et al. (2009) postulated that the southern Iraqi marshes were known by their high biological productivity due to the thick aquatic plants canopy Recent studies conclude to the same conclusion that East Hammer marsh is eutrophic. No previous studies concern CTSI of Chebiyesh marshes were traced, but in any case, it was comparable to that of East Hammer marsh (Table 6).

In general, higher CTIS values in both tidal and non-tidal marshes are due to release of untreated domestic sewage and agricultural drainage waters from the farms surrounding these marshes, as well as the congregation of buffalo herds around, beside traffic of fishing and tourist's boats in those areas. 
Hussain\& Sabbar/ Basrah J. Agric. Sci., 33(2): 172-181, 2020

Table (3): Salinity values (Practical Salinity Unit) of the study stations in Chebiyesh marshes and East Hammer marsh, during the period from spring 2018 to winter 2019

\begin{tabular}{lcccccc}
\hline Stations & \multicolumn{3}{c}{ East Hammer marsh } & \multicolumn{3}{c}{ Chebiyesh marshes } \\
\hline Salinity (PSU) & Al-Sada & Al-Mafraq & Al-Burgah & Al-Sabaghia & Abo-Sobat & Al-Baghdadia \\
\hline Spring 2018 & 3.75 & 4.7 & 5.45 & 2.2 & 2.4 & 2.95 \\
\hline Summer 2018 & 11.45 & 14 & 14.35 & 4.1 & 3.35 & 6.2 \\
\hline Autumn 2018 & 10.95 & 9.8 & 10.2 & 2.45 & 2.205 & 5.55 \\
\hline Winter 2019 & 4.3 & 5.6 & 6.85 & 2.2 & 1.95 & 2.95 \\
\hline
\end{tabular}

Table (4): TSI values in East Hammar marsh stations.

\begin{tabular}{cccc}
\hline TSI & Al-Sada & Al-Mafraq & Al-Burgah \\
\hline SPR2018 & 54.43 & 51.22 & 52.47 \\
\hline SUM2018 & 50.54 & 52.93 & 52.78 \\
\hline AUT2018 & 55.44 & 56.09 & 55.53 \\
\hline WIN2019 & 54.35 & 54.58 & 51.88 \\
\hline
\end{tabular}

Table (5): TSI values in Chebiyesh marshes stations.

\begin{tabular}{cccc}
\hline TSI & Al-Sabaghia & Abo-Sobat & Al-Baghdadia \\
\hline SPR2018 & 47.59 & 49.54 & 48.08 \\
\hline SUM2018 & 53.15 & 55.04 & 60.64 \\
\hline AUT2018 & 53.51 & 56.05 & 58.42 \\
\hline WIN2019 & 53.64 & 61.09 & 61.96 \\
\hline
\end{tabular}

PCA analysis for East Hammar marsh data (Fig. 2) indicated that Transparency affect positively the CTSI values, However total phosphorus and chlorophyll a concentrations are of inversely relationship, which could be mainly due to the obvious increase of salinity during sampling period (2018) where massive death of aquatic plants and phytoplankton in the marsh were observed as indicated recently by Al-Nagar et al. (2020). In Chebiyesh marshes the situation was opposite, all variable correlated largely with CTSI values (Fig. 3) especially total phosphorus, responsible for the deterioration of water quality of the marshes. Devi Prasad \& Siddaraju (2012) mentioned that phosphorus 
concentration was the main parameter, deciding the status of trophic condition of any aquatic ecosystem. On the other hand, Rahul et al. (2013) claimed that TSI values depend mainly on the increase of nutrients (Nitrogen and phosphorus), reflects the pressure exerted by increase human settlers on the banks of these water bodies. Determination of TSI of water bodies is an impotent step to quantified water quality and consider by many countries as vital step for successful management of these water bodies (Dodds, 2006). Moreover, many countries adopted TSI approach to determine the status of several wetlands nominated to join RAMSAR convention (Elmaci et al., 2009; Rahmati et al., 2011)

Recent studies (Hassan et al., 2011; AlSaboonchi et al., 2015; Rasheed, 2019) indicated that southern marshes were eutrophic, in compliance with present study. Our result $\mathrm{s}$ indicated that CTSI values were affected by the station depth, water current and quantity of plant cover existing at the stations as displayed in Al-Burgah and AlBagdadia both were vast openness marsh in East Hammer and Chebiyesh marshes respectively.

Table (6): Comparing The values of TSI in the present study with the other previous studies.

\begin{tabular}{ccc}
\hline Marshes & TSI & Reference \\
\hline East Hammar & $38.1-50.4$ & Al-Saboonchi et al. (2015) \\
\hline East Hammar & $9.03-43.85$ & Rasheed (2019) \\
\hline East Hammar & $50.54-56.09$ & Present study \\
\hline Chebiyesh & $47.59-61.96$ & Present study \\
\hline
\end{tabular}

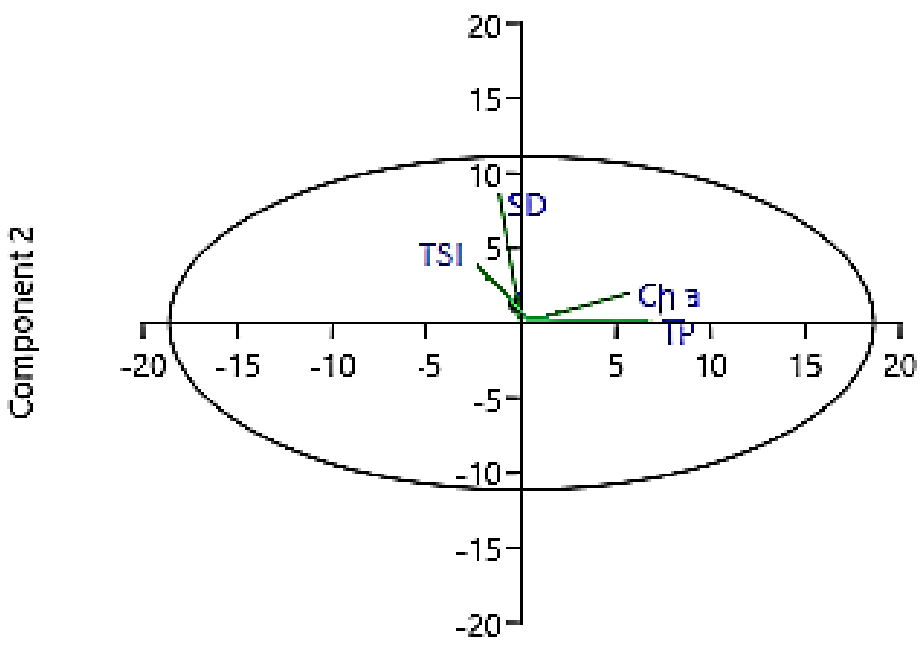

Component 1

Fig. (2): PCA analysis between TSI and input variables in East-Hammar marsh. 


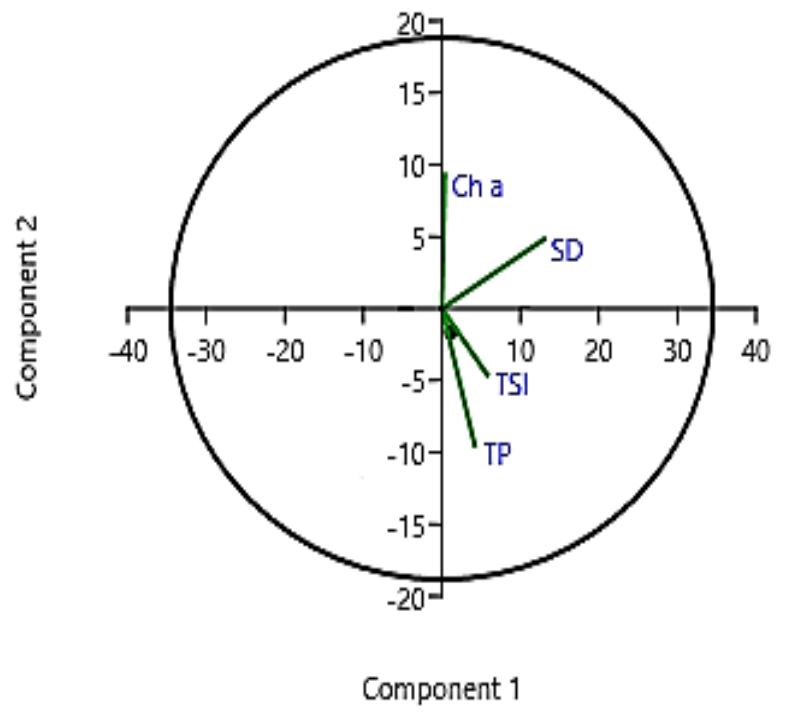

Fig. (3): PCA analysis between TSI and input variables in Chebiyesh marshes.

\section{Conclusion}

The study revealed that trophic status of southern Iraqi marshes could be deduced largely by evaluating of water depth of the marsh, chlorophyll a, phosphorus concentrations due to discharge of untreated domestic sewage and agricultural drainage waters, as well as the congregation of buffalo herds around, traffic of fishing and tourist's boats, which led to high level of organic matter and nutrients in those areas and .Other environmental parameters need to be considered such as salinity, turbidity and interrelationship between these variables..

\section{Conflicts of interest}

The authors declare that they have no conflict of interests.

A. Sabbar: http://orcid.org/0000-0003-4024-6569

\section{Acknowledgment}

The authors are grateful for Basrah Environment Directorate for providing the field work equipment and laboratory analysis.

\section{References}

Al-Abbawy, D. A. H., \& Al-Mayah, A. A. (2010). Ecological survey of aquatic macrophytes in restored marshes of southern Iraq during 2006 and
2007. Marsh Bulletin, 5, 177-196. https://marshbulletin.edu.iq/admin/file/5cc17f8991a 11.pdf

Al-Asadi, A. A. \& Al-Hejuje, M. M. (2019). Application of Organic Pollution Index (OPI) to assess the water quality of Al-Chibayish marsh, Southern Iraq. Marsh Bulletin, 14, 22-30.

Al-Hilli, M. R. A., Warner, B. G., Asada, T., \& Douabul, A. (2009). An assessment of vegetation and environmental controls in the 1970s of the Mesopotamian wetlands of southern Iraq. Wetlands Ecology and Management 17, 207-223. https://link.springer.com/article/10.1007\%2Fs 1127 3-008-9099-1

Al-Nagar, G. A., Douabul, A. A., \& Al-Noor, S. S. (2020). Water Quality Index (WQI) as indicator of the East Hammar marsh after sharpe salinity increase during summer 2018. Marsh Bulletin, 15, $1-11$. https://www.iasj.net/iasj?func=fulltext\&aId=18143 9

Al-Saboonchi, A. A., Mohamad, A. M., \& Khalid, F. (2015). Assessment of trophic status for East AlHammar marsh using trophic state index (TSI). Basrah Journal Agriculture Science, 28, 73-81.

APHA (American Public Health Association) (2005). Standard methods for examination of water and wastewater. 21th edition, Washington D. C., $1193 p p$.

https://www.standardmethods.org/?gclid=CjOKCQj wjer4BRCZARIsABK4QeVZwY9Z0RzAVknFPu3 GrrnQ- 


\section{Hussain\& Sabbar/ Basrah J. Agric. Sci., 33(2): 172-181, 2020}

JaqsIMV6jJ6HramNWRooiLhw5e7Uz8aAv0BEAL w_wcB\&

Carlson, R. E. (1977). A trophic state index for lakes: Limnology and Oceanography, 22 361-369. https://doi.org/10.4319/lo.1977.22.2.0361

Carlson, R. E. (1980). More complication in the chlorophyll. a-Secchi's disc relationship. Limnology and Oceanography, 25, 378-382. https://doi.org/10.4319/lo.1980.25.2.0379

Devi Prasad, A. G., \& Siddaraju, S. (2012). Carlson's trophic state index for the assessment of trophic status of two lakes in Mandya district. Advances in Applied Science Research, 3, 2992-2996. http://www.pelagiaresearchlibrary.com

Dodds, W. K. (2006). Eutrophication and trophic state in rivers and streams. Limnology and Oceanography, 51, 671-680. https://doi.org/10.4319/lo.2006.51.1_part_2.0671

Elmaci, A., Ozengin, N., Teksoy, A., \& Baskaya, H. S. (2009). Evaluation of trophic state of lake Uluabat, Turkey. Journal of Environmental Biology, 30, 757-760. PubMed or http://www.jeb.co.in/journal_issues/200909_sep09/ paper_24.pdf

Hassan, F. M., Al-Kubaisi, A. A., Talib, A. H., Taylor, W. D., \& Abdullah, D. S. (2011). Phytoplankton primary production in southern Iraqi marshes after restoration. Baghdad Science Journal. 8, 519-530. http://bsj.uobaghdad.edu.iq/index.php/BSJ/article/vi ew/2525

Hosmani, S. P. (2010). Trophic state index in conservation of lake ecosystems. Advances in Plant Sciences, 23, 593-596. http://wgbis.ces.iisc.ernet.in/energy/lake2006/progr amme/programme/proceedings/fullpaper_pdfs/S\%2 0P\%20Hosmani.pdf

Hussain, N. A. (2014). Biotopes of Iraqi Marshlands. 1st. edition, Difaf publishing, Beirut, 432pp. (In Arabic). https://www.neelwafurat.com/itempageMobile.aspx ?id=lbb234191-226449\&search=books

Hussain, N. A., \& Grabe , S. A. (2009). A review of the water quality of the Mesopotamian (Southern Iraq) marshes prior to the massive desiccation of the early 1990s. Marsh Bulletin, 4, 98120.https://marshbulletin.edu.iq/admin/file/592ca1c 451e4f.pdf
Hussain, N. A., Mohamed, A. R. M., Al-Noor, S. S.; Mutlak, F. M., Abed, I., \& Coad, B. W. (2009). Structure and ecological indices of fish assemblage of the recently restored Al-Hammar Marsh, southern Iraq. BioRisk, 3, 173-186. https://doi.org/10.3897/biorisk.3.11

Hussain, N. A., \& Taher, M. A. (2007). Effect of daily variations, diurnal fluctuations and tidal stage on water parameters of East Hammar marshland, Southern Iraq. Marsh Bulletin, 2, 32-42. https://www.iasj.net/iasj?func=fulltext\&aId=70642

Lind, O. T. (1979). Hand Book of Common Methods in Limnology. 2nd. edition. London: 109pp. https://www.semanticscholar.org/paper/Handbookof-common-methods-in-Limnology.-2nd-

Lind/1d5ce34267fa3635571bed9594164845e02269 08

Mitsch, W. J., \& Gosselink, J. G. (2000). Wetlands. 3rd Ed. John Wiley \& Sons, New York, 920pp. .https://doi.org/10.1002/rrr.637

Mohamed, A. M., \& Hussain, N. A. (2012). Evaluation of fish assemblage environment in east Hammar using Integrated Biological Index. Basrah Journal of Science, 30, 87-105. https://www.iasj.net/iasj?func=fulltext\&aId=69238

Rahmati, R., Pourgholam, R., Najafpour, S. H., \& Doustdar, M. (2011). Trophic status of a shallow Lake (North of Iran) based on the water quality and the phytoplankton community. World Applied Sciences Journal, 14, 112-120. http://www.idosi.org/wasj/wasj14(Food\&Environm ent)11/17.pdf

Rahul, U., Arvind, P. K., \& Upadhyay, S. K. (2013). Assessment of lake water quality by using palmer and trophic state index- a case study of upper lake, Bhopal, India, International Research Journal of Environment Sciences, 2, 1-8. http://www.isca.in/IJENS/Archive/v2/i5/1.ISCAIRJEvS-2013-024.php.

Rasheed, S. S. (2019). Qualitative and quantitative study of the planktonic and epiphytic diatoms in East Hammar marsh /Southern Iraq. M. Sc. Thesis, University of Basrah, 138pp. (In Arabic).

Richardson, C. J., \& Hussain, N. A. (2006). Restoring the Garden of Eden: An ecological assessment of the marshes of Iraq. Bioscience, 56, 477-489. https://doi.org/10.1641/00063568(2006)56[477:RTGOEA]2.0.CO;2 
Hussain\& Sabbar/ Basrah J. Agric. Sci., 33(2): 172-181, 2020

Tahir, M. A., Risen, A. K. \& Hussain, N. A. (2008). Monthly variations in the physical and chemical properties of the restored southern Iraqi marshes. Marsh Bulletin, 3, 81-94. http://www.moen.gov.iq/Portals/0/Monthly\%20vari ations $\% 20$ in $\% 20$ the $\% 20$ physical $\% 20$ and $\% 20 \mathrm{chemi}$ cal\%20properties.pdf
Yuaqub, R. R. \& Salman, H. H. (1992). Some Aspects of Selected Meteorological Element in the Marshes of Lower Mesopotamia :83-94. In: Hussain, N.A. (Ed.). Ahwar of Iraq: Environmental Approach. Marine Science Centre, University of Basrah, 299pp.

\title{
مستويات التغذية للاهوار المدية واللامدية جنوب وادي الرافدين
}

\author{
نجاح عبود حسين 1 وامل علي صبار \\ 1قسم علوم البيئة، كلية العلوم، جامعة البصرة، العراق \\ 2 دائرة حماية وتحسين البيئة في المنطقة الجنوبية، العراق
}

المستخلص: طبق دليل كارلسون لتقييم الحالة التغذوية لنوعين من اهوار جنوب العراق، اذ اختيرت ست محطات، ثلاث منها في

اهوار الجبايش اللامدية والثلاث الأخرى في اهوار شرق الحمار المدية، وتباينت قيم دليل كارلسون للمحطات الستة بين 47.95 61.96، اذ تراوحت بين المتوسطة التغذية الى المرتفعة التغذية. وكان لارتفاع الملوحة خلال 2018 تأثيرات شديدة على قيم دليل كارلسون التغذوي خاصة في هور شرق الحمار • وبصورة عامة كانت الاهوار المدية والاهوار اللامدية مرتفعة التغذية وذلك يعزى الى طرح المخلفات المنزلية غير المعالجة ومياه الصرف الزراعي. وخلصت هذه الدراسة الى ان الحالة التغذوية للأهوار العراقية الجنوبية تتأثر بثكل كبير بالنفاذية وتراكيز الكلوروفيل أ والفففور • الكلمات المفتاحية: دليل كارلسون للحالة التغذوية، المستوى التغذوي للأهوار العراقية، دليل تغذية اهوار وادي الرافدين. 